\title{
Molecular Characterisation and Identification of Three Mushrooms Found in the Niger Delta Region
}

\author{
S. B. Chuku ${ }^{{ }^{*}}$, E. O. Nwachukwu ${ }^{1}$, I. O. Agbagwa ${ }^{1}$ and H. O. Stanley ${ }^{2}$ \\ ${ }^{1}$ Department of Plant Science and Biotechnology, University of Port Harcourt, Rivers State, Nigeria. \\ ${ }^{2}$ Department of Microbiology, University of Port Harcourt, Rivers State, Nigeria.
}

\begin{abstract}
Authors' contributions
This work was carried out in collaboration among all authors. Author SBC designed the study, performed the statistical analysis, wrote the protocol and wrote the first draft of the manuscript.

Authors EON and IOA managed the analyses of the study. Author HOS managed the literature searches. All authors read and approved the final manuscript.

Article Information

DOI: $10.9734 / A R R B / 2020 / v 35 i 730253$

Editor(s):

(1) Dr. Jin-Zhi Zhang, Huazhong Agricultural University, China.

Reviewers:

(1) Mohammed Elhourri, Moulay Ismail University, Morocco. (2) Ali Abdel-hadi Mahoud Alsudani, University of Al-Qadisiyah, Iraq Complete Peer review History: http://www.sdiarticle4.com/review-history/58982
\end{abstract}

Original Research Article

Received 05 May 2020

Accepted 11 July 2020

Published 04 August 2020

\begin{abstract}
Mushrooms are a group of fungi that are diverse and in the Niger Delta region; there are various species, some of which share similar morphological features. Over the years, mushrooms have been put to several important uses ranging from food, nutraceuticals, feed for livestock, and more recently bioremediation, hence, the need for an accurate approach of identification is eminent. This study aims to identify three mushroom samples with the potential for crude oil degradation using molecular tools. The molecular identification of the mushrooms was carried out with the ITS (Internal Transcribed Spacer) region to analyze their genetic diversity. The three mushroom samples were identified as Pleurotus ostreatus, Pleurotus floridanus and Lentinus squarrosulus. The blast results showed $86.0 \%, 97.9 \%$, and $88.4 \%$ for Pleurotus ostreatus, Pleurotus floridanus and Lentinus squarrosulus respectively for sequence similarity. The samples were assigned unique accession numbers on GenBank The use of molecular characterization gives reliable results to the species level. The results from this study have increased the database of Pleurotus and Lentinus DNA and serve as a basis for the identification of unidentified species by comparing their PCR amplified sequences with ITS primers.
\end{abstract}

*Corresponding author: E-mail: sobomatechuku@gmail.com; 
Keywords: Molecular; characterization; Internal Transcribed Spacer (ITS); mushroom.

\section{INTRODUCTION}

There has been much global suffering due to increased environmental problems resulting from intensified industrialization and the use of chemicals for agricultural practices. This indiscriminate release of chemicals into the environment has caused a high level of pollution. Remediation of oil spill impacted sites in the Niger Delta after initial clean-up has so followed two (2) conventional methods viz: chemical and mechanical. These methods in themselves have had residual effects on the environment and are very expensive to carry-out. Hence, the need for eco-friendly and cost-effective methods of remediating spill sites [1]. Bioremediation uses the biological organisms' metabolic potential to degrade or transform hazardous compounds in the environment into less toxic or harmless forms $[2,3]$. The use of fungi referred to as mycoremediation, has attained widespread acceptance due to its very low substrate specificity, so they can mineralize a wide range of highly recalcitrant and persistent organopollutants $[4,5,6]$. Prospection for fungi is owing to its ability to secrete high levels of lignin modifying enzymes and other enzymes with desired properties for biotechnological applications [7]. Mushrooms belong to these physiological group known as white rot fungi known to produce lignin modifying enzymes. The need to accurately identify these species is very important as it is the first step to utilize them for various biotechnological applications. This study aims to identify the three mushroom samples using molecular tools.

\section{MATERIALS AND METHODS}

\subsection{Source of Fungi}

The fungi species used for this work were obtained from (BIODEC) Odi Bayelsa State. The samples were labelled as samples 1, 2 and 3 for the collection of indigenous mushrooms. These were transported to the laboratory immediately in zip lock bags.

\subsection{Media Preparation}

Potato dextrose agar (PDA) was used for tissue culture. This was prepared following the manufacturer's instruction using the potato dextrose agar powder (Hi-Media). To prepare 1 Litre of the media 39 grams of PDA was dissolved in 1 litre of distilled water and autoclaved at $121 \square \mathrm{C}$ for 15 minutes. Chloramphenicol $0.1 \%(\mathrm{w} / \mathrm{v})$ was added as an antibacterial agent [8].

\subsection{Tissue Culture}

This was carried out at the Regional Centre for Biotechnology and Bioresources Research laboratory, University of Port Harcourt, Choba, Rivers State, Nigeria. After surface sterilization, the inner tissue of the stipe was cut with a surgical blade already flamed and cooled around the flame area. The excised tissue was inoculated into the Petri dish with freshly poured media. The Petri dishes were immediately sealed with masking tape and cling film to avoid external contamination. The plates were then incubated for 14 days in the dark at room temperature $27 \pm 2 \square$ C. This was done for each species used $[9,10]$. Sub-culturing was done several times to obtain a pure culture.

\subsection{Molecular Characterisation}

\subsubsection{DNA extraction}

A slight modification of the cetyltrimethylammonium bromide (CTAB) Method [11] mycelium was scraped off and transferred to already sterilized mortar. DNA was extracted with Zymo Quick DNA Fungal /Bacterial miniprep Kit, with the following steps as stated by the manufacturer Zymo Research group CA, USA. For DNA extraction, a five (5) days old culture of the three samples $(1,2$ and $3)$. The extracted DNA was stored in the freezer and maintained on ice to avoid denaturation.

\subsubsection{DNA quantification}

This step was done to determine the concentration and purity of the extracted DNA using the NanoDrop 2000c Spectrophotometer (Thermo Fisher Scientific Inc., Wilmington, Delaware, USA). The sample was vortexed briefly to homogenize. $1.7 \mu \mathrm{L}$ of the extracted DNA was used. Then sample concentration $\mu \mathrm{g} / \mu \mathrm{l}$ was measured absorbance at $260 / 280 \mathrm{~nm}$ wavelength appropriate for nucleic acid sample. This reading was taken in triplicates [11,12].

\subsubsection{DNA quality check}

To determine the quality of extracted DNA, Agarose gel electrophoresis method was adopted to determine the quality of nucleic acid 
extracted [13]. The gel was viewed in a gel documentation system by exposing it to UV light and pictures were taken to show the DNA Bands.

\subsection{Polymerase Chain Reaction (PCR)}

PCR Amplification of DNA samples was done using universal primers in a thermal cycler (GeneAmp PCR system 9700). ITS4: Reverse (5'- TCCTCCGCTTATTGATATGC-3') and ITS5: Forward (5'- GGAAGTAAAAGTCGTAACAAGG $\left.3^{\prime}\right)[14,15,16]$. The total reaction volume of $25 \mu \mathrm{l}$ made up of $2.5 \mu$ l of $10 x$ PCR buffer, $1 \mu \mathrm{l}$ of $25 \mathrm{mM}$ $\mathrm{MgCl}_{2}, 1 \mu \mathrm{l}$ each of the forward primer and reverse primer, $1 \mu \mathrm{l}$ of DMSO, $2 \mu \mathrm{l}$ of $2.5 \mathrm{Mm}$ DNTPs, $0.1 \mu \mathrm{l}$ of $5 \mu / \mu \mathrm{l}$ Taq DNA polymerase, and $3 \mu \mathrm{l}$ of $10 \mathrm{ng} / \mu \mathrm{l}$ DNA and $13.4 \mu \mathrm{l}$ Nuclease free water. The PCR cycling parameters: Initial denaturation at $94 \mathrm{C}$ for $5 \mathrm{mins}$, followed by 36 cycles of denaturation at $94 \square \mathrm{C}$ for $30 \mathrm{sec}$, annealing at $54 \square \mathrm{C}$ for 30 secs and elongation at $72 \square \mathrm{C}$ for $45 \mathrm{sec}$. Followed by a final elongation step at $72 \square \mathrm{C}$ for 7 minutes. Amplified fragments were visualized on Safe view- stained 1.5\% agarose electrophoresis gels and photographed under UV light in a gel documentation system. A $1 \mathrm{~kb}$ ladder (Bioline) used as a marker for the gel run served as control.

\subsection{Sequencing and Bioinformatic Analysis}

The products of PCR were subjected to Sanger dideoxy sequencing at IITA, Ibadan, Nigeria. The sequences obtained were deposited to the GenBank database to compare with the National Center for Biotechnology Information (NCBI) using the basic local alignment search tool (BLAST) algorithm [17]. Phylogenetic trees were constructed for each organism using the best Basic Local Alignment Search Tool BLAST hits Multiple sequence alignment with the Clustal W algorithm and the phylogenetic trees showing maximum likelihood algorithm (Juke-Cantor) was obtained on (MEGA) version 8 [18].

\section{RESULTS AND DISCUSSION}

DNA concentration range from $26.6 \mathrm{ng} / \mu \mathrm{L}$ to $30.53 \mathrm{ng} / \mu \mathrm{L}$ for the samples while DNA purity range from 1.66 to 1.79 respectively. Quality check was then conducted on agarose gel which produced single bands of intact DNA when viewed on the gel with a gel documentation system, the result is as shown in plate 1 . The results obtained indicated that the extracted DNA were qualified and appropriate for further molecular analysis. The results indicate contaminants like proteins or phenols are absent with the lower and higher range respectively $[19,20]$.

\subsection{Concentration and Purity of Extracted Nucleic Acid (DNA)}

\subsubsection{PCR amplification}

Isolated DNA from the samples used was amplified with ITS primers (ITS-4 and ITS-5). The amplified products obtained were visualized on Safe view- stained $1.5 \%$ agarose electrophoresis gel. They appeared as single intact bands on the agarose gel with safe view-stain as shown in the plate below. The size of the PCR fragment for all the samples was deduced with the ladder used. Products of PCR migrated between $654 \mathrm{bp}$ and $727 \mathrm{bp}$ as shown in Plate 2. The result of all the mushrooms was within the range (350 and 880 bp) for fungi species using ITS 1 and ITS 4 [21] and the range of (651 and $800 \mathrm{bp}$ ) [22].

Amplicons of PCR using Internal transcribed spacer primers of the test samples were sequenced and BLAST analysis was done to obtain phylogenetic trees (Figs. 1-3). The result of the full length ITS sequences obtained for the samples were deposited to the GenBank Nucleotide Database NCBI (Nucleotide Center for Biotechnology Information) with the strain numbers. The submission was subsequently assigned unique accession numbers as shown in Table 1. The blast results showed significant sequences similar to the query sequences used to identify the organisms as given in the Table 2 with their respective percentage similarities. Blast results have identified the samples used as three different species belonging to the basidiomycetes. The sequences of strains obtained after the sequencing of ITS PCR

Table 1. Concentration and Purity of DNA extracted from the samples used

\begin{tabular}{lll}
\hline Sample ID & DNA concentration $(\mathbf{n g} / \mathbf{\mu L})$ & DNA Purity $(\mathbf{2 6 0 / 2 8 0} \mathbf{n m})$ \\
\hline 1 & $29.97 \pm 2.73$ & $1.79 \pm 0.05$ \\
2 & $30.53 \pm 0.40$ & $1.66 \pm 0.01$ \\
3 & $26.60 \pm 1.41$ & $1.66 \pm 0.01$ \\
\hline & Each value is the mean of three replicates \pm standard deviation
\end{tabular}


products were used to generate phylogenetic trees generated by Maximum composite likelihood analysis showing sample 1 as
Pleurotus ostreatus, sample 2 as Pleurotus floridanus and sample 3 as Lentinus squarrosulus respectively.

\section{$1 \quad 2 \quad 3$}

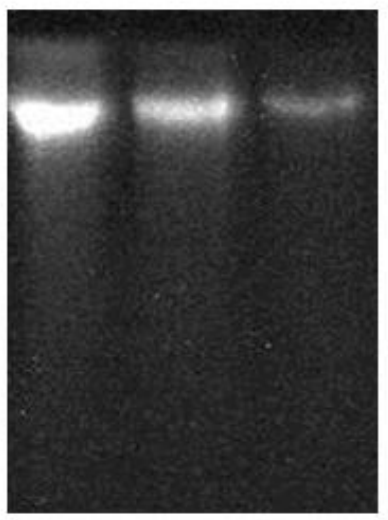

Plate 1. Agarose gel photograph of DNA extracted of the three samples used lane 1-3 representing samples 1-3 respectively

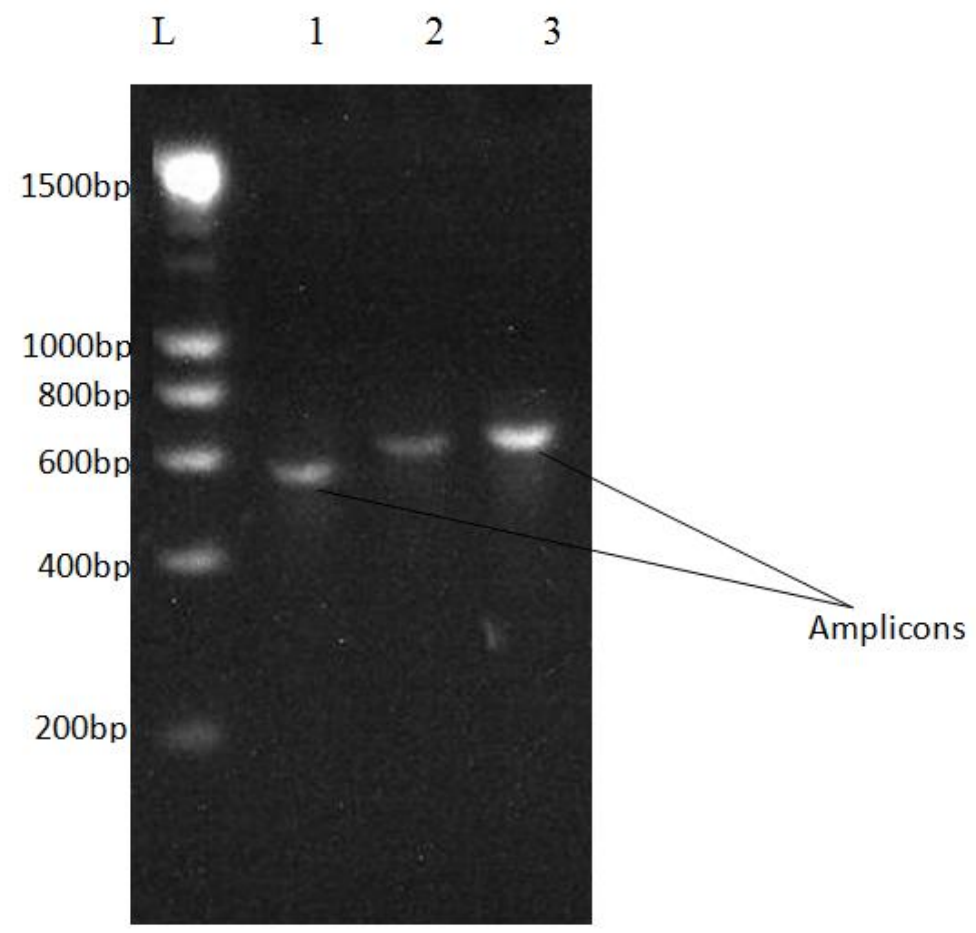

Plate 2. Amplicons obtained from a polymerase chain reaction of the internal transcribed spacer (ITS) region of the fungi understudy

$L-1 K b$ DNA Ladder (Bioline), The numbers represent the samples used 
Table 2. Taxonomic affinities of samples with blast searches of ITS sequences on GenBank

\begin{tabular}{llll}
\hline Sample id & $\begin{array}{l}\text { Taxonomic affinity } \\
\text { (Gene Bank No.) }\end{array}$ & $\begin{array}{l}\text { Percentage similarity } \\
\text { (\%) }\end{array}$ & $\begin{array}{l}\text { Accession } \\
\text { number }\end{array}$ \\
\hline 1 & Pleurotus ostreatus (MN049516.1) & 86.00 & MN968774 \\
2 & Pleurotus floridanus (MN173381.1) & 97.88 & MN968775 \\
3 & Lentinus squarrosulus (KT273380.1) & 88.44 & MN968776 \\
\hline
\end{tabular}

Pleurotus ostreatus (MN049516.1)

Pleurotus sapidus (MK281339.1)

Pleurotus floridanus (MK281340.1)

Phlebiopsis gigantea (EF174450.1)

RCBBR AEASO1

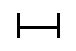

0.20

Fig. 1. Phylogenetic tree generated by Maximum composite likelihood analysis based on the ITS 1-2 gene sequences

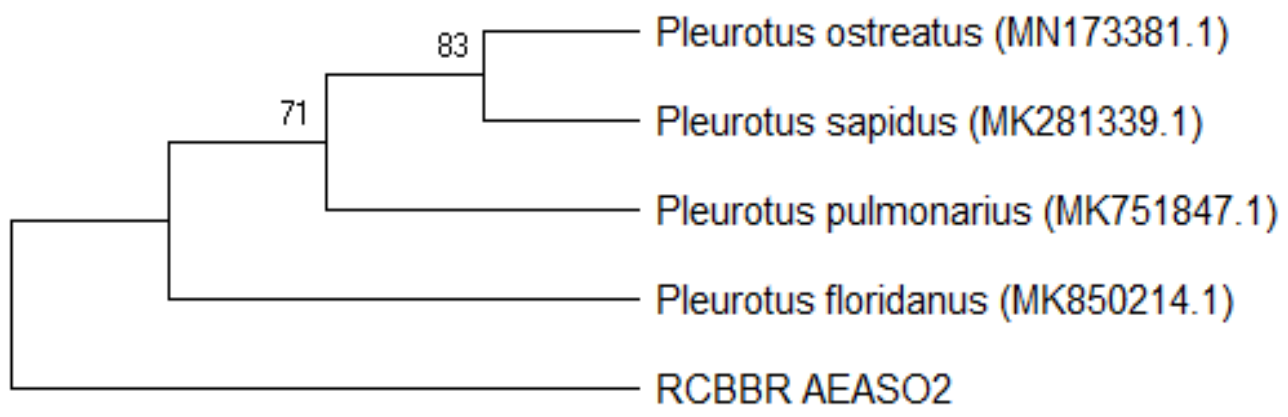

Fig. 2. Phylogenetic tree generated by Maximum composite likelihood analysis based on the ITS 1-2 gene sequences 


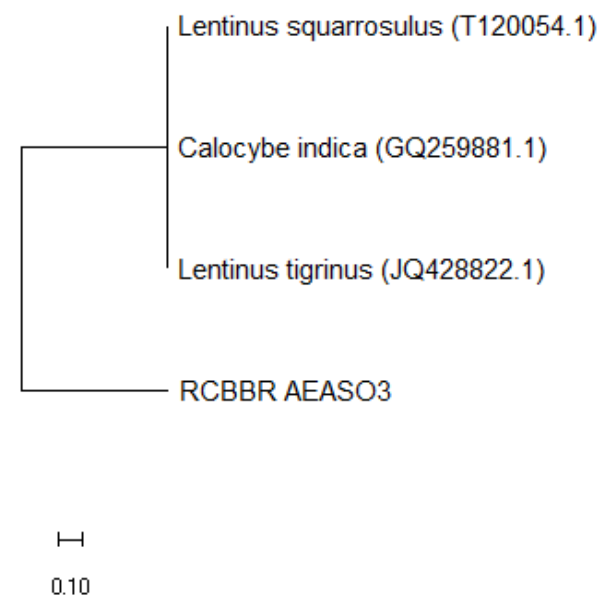

Fig. 3. Phylogenetic tree generated by Maximum composite likelihood analysis based on the ITS 1-2 gene sequences

\section{CONCLUSION}

The mushrooms in the Niger Delta region are diverse. Most of them share identical features which could lead to conflicting results making it inappropriate to rely on morphological characterization for identification. The use of molecular characterization gives reliable results to the species level. The results from this study have increased the database of Pleurotus and Lentinus DNA and serve as a basis for the identification of unidentified species by comparing their PCR amplified sequences with ITS primers.

\section{COMPETING INTERESTS}

Authors have declared that no competing interests exist.

\section{REFERENCES}

1. Hamman S. Bioremediation capabilities of white rot fungi. Biodegradation. 2004;52:15.

DOI:10.5897/BMBR12.006.

2. Watanabe K. Microorganisms relevant to bioremediation. Current Opinion in Biotechnology. 2001;12:237- 241. DOI: 10.1016/s0958-1669(00)00205-6.

3. Yadav AN, Mishra S, Singh S, Gupta A. Recent advancement in white biotechnology through fungi. Volume 2: perspective for value-added products and environments. Springer International Publishing, Cham. 2019;119- 148.
4. Pointing S. Feasibility of bioremediation by white-rot fungi. Applied Microbiology Biotechnology. 2001;57:20-33.

DOI: $10.1007 / \mathrm{s} 002530100745$.

5. Mansur $M$, Arias ME, Copa-Patiño JL, Flärdh $\mathrm{M}$, and González $\mathrm{AE}$. The white-rot fungus Pleurotus ostreatus secretes laccase isozymes with different substrate specificities. Mycologia. 2003;95:10131020.

DOI:10.1080/15572536.2004.11833017.

6. Adenipekun $\mathrm{CO}$, Lawal $\mathrm{R}$. Uses of mushrooms in bioremediation: A review. Biotechnology and Molecular Biology Reviews. 2012;7(3):62-68. Available:https://doi.org/10.5897/BMBR12. 006.

7. Adebayo EA, Oloke JK, Yadav A, Bora TC. Improvement of Laccase Production in Pleurotus pulmonarius-LAU 09 by Mutation. Journal of Microbiology Research. 2012;2(1):11-17. DOI:10.5923/j.microbiology.20120201.03.

8. Zheng RS, Wang WL, Tan J, Xu H, Zhan RT, Chen WW. An investigation of fungal contamination on the surface of medicinal herbs in China. Chinese medicine. 2017;12:2.

Available:https://doi.org/10.1186/s13020016-0124-7.

9. Bankole PO, Adekunle AA. Studies on biodiversity of some mushrooms collected in Lagos State, Nigeria using biotechnological methods. Journal of Yeast and Fungal Research. 2012;3(4):37- 48. DOI:10.5897/JYFR12.008 
10. Chuku SB, Nwachukwu EO, Stanley HO. Effects of selected culture media on mycelial growth of oyster mushroom (Pleurotus ostreatus). African Journal of Biotechnology. 2015;14(17):1471-1474.

Available:https://doi.org/10.5897/AJB2014. 14318.

11. Adedokun OM, Kyalo M, Gnonlonfin B, Wainaina J, Githae D, Skilton R, Harvey J. Mushroom: Molecular characterization of indigenous species in the Niger Delta Region of Nigeria. European Journal of Horticultural Science. 2016;81(5):273-280. Available:https://doi.org/10.17660/eJHS.20 16/81.5.6.

12. Khan KB, Arshan MK, Akram AS, Jaffar $\mathrm{AH}$. Comparative study on DNA extraction methods for PCR amplification of $\mathrm{COI}$ gene from ascidians of Indian coast. International Journal of Zoology Studies. 2018;3(2):132-134.

13. Lee PY, Costumbrado J, Hsu CY, Kim YH. Agarose Gel Electrophoresis for the Separation of DNA Fragments. Journal of Visualized Experiments. 2012;62:1-5. DOI:10.3791/3923.

14. White T, Bruns T, Lee S, Taylor J. Amplification and direct sequencing of fungal ribosomal RNA genes for phylogenetics. In PCR protocols, M. Innis, D. Gelfand, J. Sninsky and T. White, eds., (San Diego, California: Academic Press). 1990;315-322.

DOI:org/10.1016/b978-0-12-3721808.50042-1.

15. Bellemain E, Carslen T, Brochmann C, Coissac E, Taberlet P. Kauserud H. ITS as an environmental DNA barcode for fungi: an in silico approach reveals potential PCR biases. Biomed Central Microbiology. 2010;10:189.

DOI:ORG/10.1186/1471-2180-10-189.

16. Gao H, Wong Y, Zhang W, Wang W, Mu Z. Isolation, identification and application in lignin degradation of an ascomycetes $\mathrm{GHJ}$ 4. African Journal of Biotechnology. 2011;10(20):4166- 4174.

DOI:10.5897/AJB10.2250

17. Chang W, Coppola TW. Submitting a Sequence to GenBank. Current Protocol Essential Laboratory Technique. 2009;1(1):1-2.

DOI:ORG/10.1002/9780470089941.ET110 $2 \mathrm{~S} 01$.

18. Tamura K, Peterson D, Peterson N, Stecher G, Nei M, Kumar S. MEGA5: molecular evolutionary genetics analysis using maximum likelihood, evolutionary distance and maximum parsimony methods. Molecular Biology and Evolution. 2011;28:2731-2739.

DOI:10.1093/molbev/msr121.

19. Couto MCM, Sudre AP, Lima MF, Bomfim TCB. Comparison of techniques for DNA extraction and agarose gel staining of DNA fragments using samples of Cryptosporidium. Veterinarni Medicina. 2013;58(10):535-542.

20. Lucena-Aguilar G, Sanchez-Lopez AM, Barberan-Aceituno C, Carrillo-Avila JA, Lopez-Guerrero JA, Aguilar-Quesada R. DNA Source Selection for Downstream Applications Based on DNA Quality Indicators Analysis. Biopreservation and Biobanking. 2016;14(4):26470. DOI:10.1089/bio.2015.0064.

21. Fujita SI, Senda Y, Nakaguchi S, Hashimoto T. Multiplex PCR using internal transcribed spacer 1 and 2 regions for rapid detection and identification of yeast strains. Journal of Clinical Microbiology. 2001;39(10):3617-3622.

DOI: 10.1128/JCM.39.10.3617-3622.2001.

22. Imtiaj A, Lee TS, Ohga S. Sequence variation of Pleurotus species collected from Eastern Asia. Micología Aplicada International. 2011;23(1): 1-10.

(c) 2020 Chuku et al.; This is an Open Access article distributed under the terms of the Creative Commons Attribution License (http://creativecommons.org/licenses/by/4.0), which permits unrestricted use, distribution, and reproduction in any medium, provided the original work is properly cited.

Peer-review history:

The peer review history for this paper can be accessed here: http://www.sdiarticle4.com/review-history/58982 